\title{
Management of severe respiratory failure following influenza A H1N1 pneumonia
}

\author{
Michela Vivarelli, ${ }^{1}$ Alessandro Perazzo, ${ }^{2}$ Piergiorgio Gatto, ${ }^{2}$ Paola Antonella Truglio, ${ }^{1}$ Mario Santo, ${ }^{1}$ \\ Gianluca Ferraioli, ${ }^{3}$ Antonello Nicolini ${ }^{2}$
}

${ }^{1}$ SC Medicina d'Urgenza, Ospedale di Lavagna (GE); ${ }^{2}$ UO Pneumologia, Ospedale di Sestri Levante (GE); ${ }^{3}$ Dipartimento Emergenza ASL 4 Chiavarese (GE), Italy

\begin{abstract}
The use of non-invasive ventilation (NIV) in severe hypoxemic respiratory failure $\left(\mathrm{PaO}_{2} / \mathrm{FIO}_{2} \leq 250\right)$ due to $\mathrm{H} 1 \mathrm{H} 1$ virus pneumonia is controversial. In this prospective study, we aimed to assess the efficacy of NIV in avoiding endotracheal intubation and to identify predictors of success or failure. Nineteen patients with $\mathrm{H} 1 \mathrm{~N} 1$ viral pneumonia had severe respiratory failure $\left(\mathrm{PaO}_{2} / \mathrm{FIO}_{2}\right.$ ratio $\leq 250$ ). Five patients with $\mathrm{PaO}_{2} / \mathrm{FIO}_{2}$ lower than 150 and simplified acute physiology score (SAPS II) lower than 34 underwent NIV and were admitted to the Intensive Care Unit and received NIV as first-line therapy. NIV failed in 2 of the 14 patients but had a good outcome in 12. None of the patients treated with NIV died. The duration of NIV was $5.0 \pm 1.9$ days and the hospital stay was $11.3 \pm 1.2$ days. The average $\mathrm{PaO}_{2} / \mathrm{FIO}_{2}$ ratio after $1 \mathrm{~h}$ of NIV was $239.1+38.7$. No patient had multi-organ failure. $\mathrm{PaO} / 2 / \mathrm{FIO}_{2}$ ratio after $1 \mathrm{~h}$ and SAPS II at admission were independent variables correlated with the success of NIV. In our study, NIV was successful in 12 of the 14 patients $(85.7 \%)$ and this is one of the highest success rates in the literature. In our opinion, the reason for these results is the strict selection of patients with severe respiratory failure $\left(\mathrm{PaO}_{2} / \mathrm{FIO}_{2}\right.$ ratio $\left.\geq 150\right)$ and the strict following of predictors of success for NIV such as SAPS II of 34 or lower and $\mathrm{PaO}_{2} / \mathrm{FIO}_{2}$ ratio of 175 or lower after $1 \mathrm{~h}$ of NIV. Clinicians should be aware of pulmonary complications of influenza A H1N1 and strictly select the patients to undergo NIV. NIV could have an effective and safe role in reducing the high demand for critical care beds, particularly during the pandemic.
\end{abstract}

\section{Introduction}

The use of non-invasive ventilation (NIV) in severe hypoxemic respiratory failure is still a subject of

Correspondence: Nicolini Antonello, UO Pneumologia, Ospedale Generale, via Terzi 43, 16039 Sestri Levante (GE), Italy. Tel. +39.0185329145.

E-mail: antonello.nicolini@fastwebnet.it

Key words: influenza A H1N1, severe respiratory failure, noninvasive ventilation.

Contributions: MS and AN had access to data and are responsible for their soundness and the accuracy of the study and analysis.

Acknowledgments: the authors thank Dr Maura Ferrari-Bravo for her help in statistical analysis, and Gabriella Porfido, Patrizia Bono, Stefania Ballone, Piera Calvetti, Laura Beccarelli, Sabrina Mannina, Raffaella De Vincenzi, Ilaria Brogioli, Francesca Rocca and Vilma Capitanio for help with collecting and processing clinical data.

Conflicts of interest: the authors declare no potential conflicts of interest.

This work is licensed under a Creative Commons Attribution NonCommercial 3.0 License (CC BY-NC 3.0).

CCopyright M. Vivarelli et al., 2013

Licensee PAGEPress, Italy

Italian Journal of Medicine 2013; 7:293-299

doi:10.4081/itjm.2013.293 controversy. However, in centers that have matured some years of experience, used early, NIV ${ }^{1,2}$ avoids the need for orotracheal intubation in $30-50 \%$ of patients. ${ }^{1,3}$ Non-invasive ventilation is not recommended in patients with influenza H1N1 virus complicated by pneumonia, acute lung injury (ALI) or acute respiratory distress syndrome (ARDS). In fact, some Authors have shown that this method, although useful in improving oxygenation, is not necessarily capable of modifying the natural disease course. ${ }^{4-6}$ Given this, many Authors have reported high percentages of failure of NIV in cases of pneumonia in influenza H1N1 pandemics..$^{5-9}$ Nevertheless, other Authors have more recently reported the efficacy of NIV in some cases of severe respiratory failure associated to $\mathrm{H} 1 \mathrm{~N} 1 \mathrm{pneu}-$ monia. ${ }^{10,11}$ Estenssero et al. ${ }^{12}$ presented a study of 337 patients with pneumonia from A H1N1 influenza who underwent mechanical ventilation. Data were collected from 35 Intensive Care Units (ICU) in Argentina. Sixty-four of them were treated with NIV and its use was associated with better outcome, perhaps due to the fact that this type of intervention was reserved for those patients with less severe hypoxemia.

In a recent study examining what was learnt from experiences in an ICU setting during an influenza A H1N1 pandemic, Rodriguez et al. ${ }^{13}$ reported a high failure rate with NIV (75\%) and a recent meta-analysis suggested that NIV does not reduce the need for intubation. There is insufficient evidence to be able to support the routine use of NIV in severe hypoxemic 
respiratory failure. ${ }^{14}$ An opposite point of view concerns the use of NIV in women during pregnancy. Djibrè et $a l .{ }^{10}$ reported the case of a pregnant woman with acute severe respiratory failure due to pneumonia associated with H1N1 infection successfully treated with NIV, but various other Authors, because of the risk of harming the fetus have suggested a more cautious approach, preferring to use tracheal intubation. ${ }^{15}$ Recently, the debate in the literature about the use of NIV in H1N1 pneumonia has been continued after the death of 4 Mexican patients who died while waiting for beds in the ICU to become available. ${ }^{16}$ Must NIV be considered a highrisk procedure? Does NIV represent an effective means of ventilation in this setting? Our study aims to help find an answer to these questions.

\section{Materials and Methods}

\section{Inclusion and exclusion criteria}

This prospective study was started in September 2009 and was completed in March 2012. The study was conducted at the General Hospital of Sestri Levante and Lavagna, in Liguria in northwestern Italy. Communityacquired pneumonia was diagnosed by the presence of a new infiltrate on chest X-ray associated with symptoms of infection of the lower respiratory tract. $\mathrm{PaO}_{2} / \mathrm{FIO}_{2}$ ratio of 250 or under with high-flow oxygen therapy administered via Venturi mask was considered index of acute severe respiratory failure. The two hospital centers share an Emergency Department where a special screening program was developed to allow for the quick diagnosis of $\mathrm{H} 1 \mathrm{~N} 1$ viral infection and prompt hospital admission in a protected environment (intensive therapy, semi-intensive respiratory therapy, and semi-intensive medical care) to avoid the infection spreading. ${ }^{17}$ Exclusion criteria were hospitalization within the previous ten days or concomitant pulmonary neoplasias or tuberculosis. Further exclusion criteria were: need for immediate intubation for cardiac-respiratory arrest, severe hemodynamic instability, organ failure in 2 or more organs, severe encephalopathy, and all conditions that do not allow NIV to be used, such as tracheostomy, facial deformity and recent maxilla-facial or gastro-enteric surgery.

\section{Patients}

Forty patients were seen in the Emergency Department with a diagnosis of H1N1 pneumonia confirmed by laboratory tests. Patients presented fever, influenzalike symptoms and had contracted viral A H1N1 influenza; the specific subtype was confirmed by a nasopharyngeal tampon using real-time transcriptase polymerase chain reaction. Twenty-seven of these patients presented a hypoxemic profile $\left(\mathrm{PaO}_{2} \leq 60 \mathrm{~mm}\right.$ $\mathrm{Hg}$ ) but only 19 were included in the study. Disease severity was evaluated using the simplified acute physiology score (SAPS II) and the $\mathrm{PaO}_{2} / \mathrm{FIO}_{2}$ (ratio between partial pressure of $\mathrm{O}_{2}$ arterial therapy and the fraction of $\mathrm{O}_{2}$ inhaled at high-flow of oxygen with a mask) $(\mathrm{P} / \mathrm{F})$ calculated on admission. Five patients with $\mathrm{PaO}_{2} / \mathrm{FIO}_{2}$ ratio less than 150 , SAPS II over 34 and multi-lobular pneumonia underwent invasive mechanical ventilation and were admitted to the ICU.,19 Another 14 patients with $\mathrm{PaO}_{2} / \mathrm{FIO}_{2}$ ratio over 150 , SAPS II below 34 and bilateral focal infiltrates were admitted to a sub-intensive care medical or pneumology unit and treated with NIV.

\section{Care setting}

The two semi-intensive medical and pneumology units are located on the two different hospital sites. The first is located in the Lavagna Hospital where the Emergency Department and general ICU are to be found, while the second is located in the Sestri Levante Hospital. The semi-intensive medical unit in Lavagna has 8 beds and the semi-intensive pneumology unit in Sestri Levante has 4 beds and is equipped with continuous non-invasive monitoring systems and intensive and semi-intensive care pulmonary ventilators, including NIV. A nurse specialized in the care of critical patients is available round the clock (24/7). Immediate availability of an Internal Medicine doctor is also available 24/7. In the Lavagna Hospital a reanimation specialist is also available. A pneumologist is available during the day $(12 \mathrm{~h})$ in the sub-intensive pneumology unit with additional on-call availability of the pneumologist and the reanimation specialist at night.

\section{Data collection}

The following parameters were recorded on admission: age, gender, any comorbidities, number of pulmonary lobes involved at chest X-ray or computerized tomography (CT) scan, $\mathrm{PaO}_{2}, \mathrm{PaCO}_{2}, \mathrm{pH}$, $\mathrm{PaO}_{2} / \mathrm{FIO}_{2}$ ratio (P/F), SAPS II, ventilation approach, ventilator set-up and setting, and $\mathrm{PaO}_{2} / \mathrm{FIO}_{2}$ ratio after $1 \mathrm{~h}$ of NIV. Furthermore, all patients were evaluated on admission and daily during follow up, checking for hypotension ( $\leq 90 \mathrm{mmHg}$ ), confused mental state, intubation and invasive mechanical ventilation (IMV).

Each patient undergoing NIV who did not achieve an improvement in $\mathrm{PaO}_{2} / \mathrm{FIO}_{2}$ ratio over 175 after $1 \mathrm{~h}$ was re-evaluated, transferred to the ICU and underwent invasive ventilation. Ventilators with a special NIV platform were used with bilevel positive airway pressure (BIPAP) or pressure support ventilation (PSV) or in continuous positive airway pressure (CPAP). CPAP and aspiration with positive pressure of the airways (EPAP) were set to obtain $\mathrm{PaO}_{2} \geq 60$ $\mathrm{mmHg}$ or $\mathrm{spO}_{2} \geq 90 \%$. Inhalation pressure in airways (IPAP) was increased, starting with $10 \mathrm{~cm} \mathrm{H}_{2} \mathrm{O}$, with 
subsequent increases of 2-3 $\mathrm{cm} \mathrm{H}_{2} \mathrm{O}$ until obtaining 6$8 \mathrm{~mL} / \mathrm{kg}$ volume and a respiratory frequency $\leq 30$ breaths/min. NIV was considered efficient in cases of continuous improvement of oxygenation ( $\mathrm{P} / \mathrm{F}$ ratio) and when the patient did not feel the need for ventilation after at least $48 \mathrm{~h}$ of treatment, maintaining $\mathrm{p} \mathrm{O}_{2}$ over $60 \mathrm{mmHg}$ or a saturated $\mathrm{O}_{2}$ over $90 \%$ with maximum $\mathrm{FiO}_{2} 40 \%$.

\section{Statistical analysis}

Continuous variables were compared using univariate regression test (covariance analysis) with categorical variables as outcome (intubation). Logistical regression model was performed for categorical variable to predict risk factors related to NIV failure. Independent variables evaluated were: age, gender, any comorbidities, number of pulmonary lobes involved, SAPS II and P/F on admission and after $1 \mathrm{~h}$ of NIV, and length of hospital stay. All analyses were performed with R-Project software (version 2.13.2; R-Foundation, Vienna, Austria). $\mathrm{P} \leq 0.05$ was considered statistically significant.

\section{Ethics}

This study was carried out according to the Declaration of Helsinki and was approved by the institutional ethics committee, Chiavari, Liguria, Italy. All patients provided informed consent.

\section{Results}

Among the 19 patients presenting acute respiratory failure, 5 patients ( 3 males and 2 patients) were immediately subjected to invasive ventilation while the remaining 14 were treated with NIV. Initial value of $\mathrm{PaO}_{2}$ for patients undergoing NIV was $44.6 \pm 12.5$ $\mathrm{mmHg}, \mathrm{PaCO}_{2} 38.2 \pm 5.06 \mathrm{mmHg}, \mathrm{pH} 7.41 \pm 4.8$ $\mathrm{mmHg}, \mathrm{paO}_{2} / \mathrm{FiO}_{2} 181.2 \pm 26.7$, SAPS II $17.6 \pm 2.5$ and $\mathrm{PaO}_{2} / \mathrm{FIO}_{2}$ after 1 h 239.1 \pm 38.7 . Figure 1 shows changes over time in $\mathrm{PaO}_{2} / \mathrm{FIO}_{2}$ ratio during NIV. Number of lobes involved at X-ray and/or CT scan was 3.0 \pm 0.6 , duration of NIV was $104.5 \pm 47.6$, and hospital stay was $11.3 \pm 1.2$ days. All patients were effectively treated with NIV except for 2 who were subsequently treated with IMV; both patients survived. Of these 2 patients who were subsequently intubated, one was treated with BIPAP and one with PSV. In both cases, new pulmonary infiltrates and a deterioration in the respiratory profile led to a general worsening of their condition.

The general characteristics of patients who underwent IMV and NIV are shown in Table 1. Twelve patients were successfully treated: 10 with BIPAP or PSV, 2 with CPAP. For the 10 patients treated with BIPAP or PSV, average IPAP was $18.4 \pm 2.4 \mathrm{~cm} \mathrm{H}_{2} \mathrm{O}$ (range $15-22 \mathrm{~cm} \mathrm{H}_{2} \mathrm{O}$ ) and average EPAP was $6.0 \pm 0.9$ $\mathrm{cm} \mathrm{H}_{2} \mathrm{O}$ (range 5-8 $\mathrm{cm} \mathrm{H}_{2} \mathrm{O}$ ). For the 2 patients treated with $\mathrm{CPAP}$, average value was $12.5 \pm 2.6 \mathrm{~cm} \mathrm{H}_{2} \mathrm{O}$

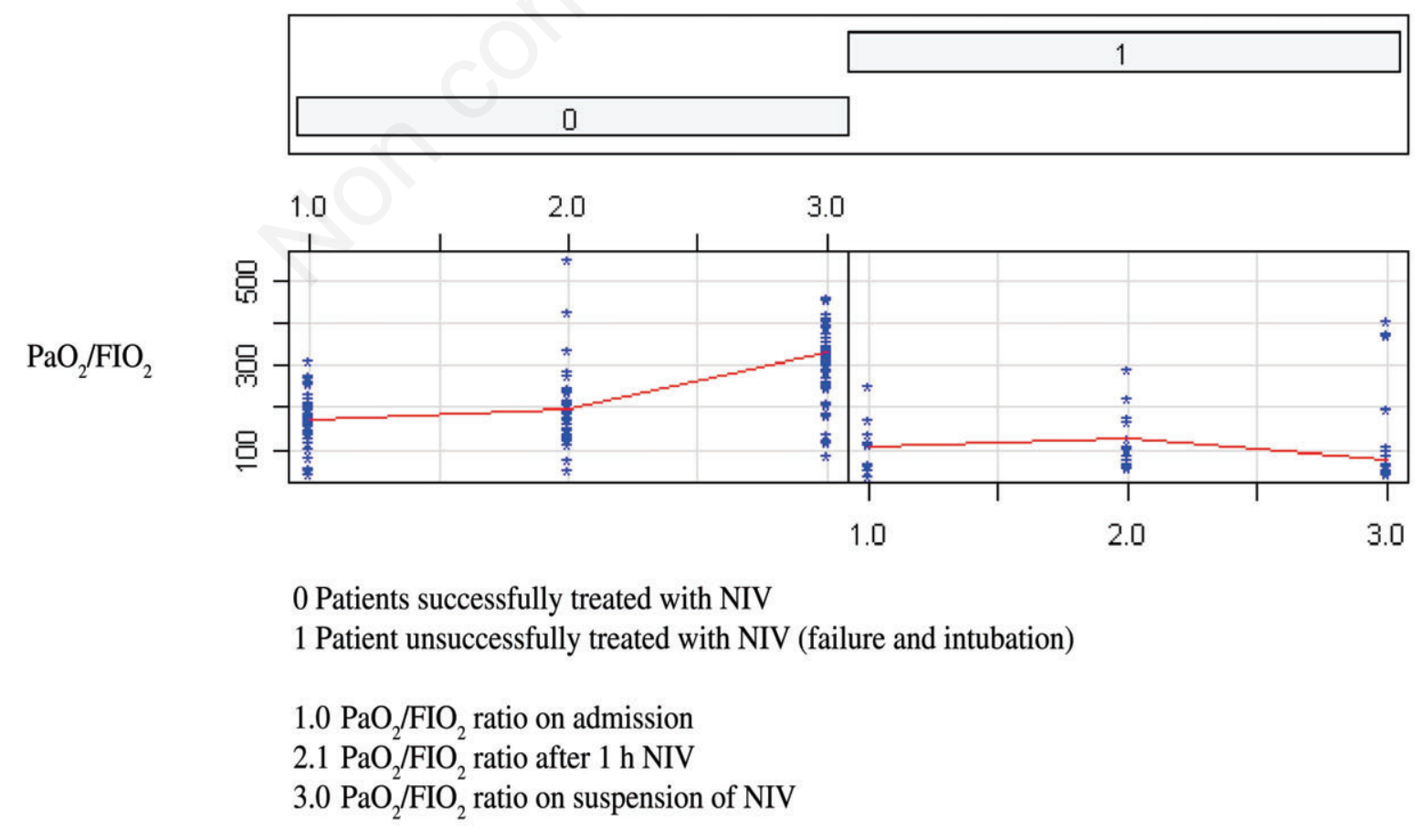

Figure 1. Changes over time in $\mathrm{PaO}_{2} / \mathrm{FiO}_{2}$ ratio during non-invasive ventilation (NIV). 
(range 10-16 $\mathrm{cm} \mathrm{H}_{2} \mathrm{O}$ ). Average oxygen fraction was $45.5 \pm 14.5$ (range $30-60 \%$ ). Non-invasive mechanical ventilation was only provided via an oro-nasal mask in patients undergoing BIPAP or PSV while other types of interface, total facemask or cap/helmet were used in patients undergoing CPAP. It must be emphasized that the CPAP approach was only used as an intrinsic method of pulmonary ventilation and at medium-high values that allowed oxygen saturation and flow volumes sufficient for the pathology; these were continuously monitored on the ventilator display.

Patients' characteristics, ventilation approaches and the ventilator settings used in patients treated with NIV who had a positive outcome are shown in Table 2. Statistically significant factors, according to logistical regression analyses and univariate regression analyses associated with successful NIV are shown in Table 3.
Table 1. General characteristics of patients who underwent invasive mechanical ventilation and non-invasive ventilation.

\begin{tabular}{lcc}
\hline Patients & Intubation (5 patients) & NIV (14 patients) \\
\hline Age & $57.3 \pm 18.6$ & $48.1 \pm 20.6$ \\
\hline Gender (M/F) & $3 / 2$ & $9 / 5$ \\
\hline Comorbidity & $4 / 5$ & $6 / 14$ \\
\hline No. lobes & $3.9 \pm 0.6$ & $3.0 \pm 0.6$ \\
\hline P/F on admission & $155.0 \pm 21.5$ & $181.2 \pm 26.7$ \\
\hline P/F after 1 h NIV & $166.5 \pm 42.2$ & $239.1 \pm 38.7$ \\
\hline SAPS II & $38.5 \pm 19.6$ & $18.3 \pm 3.0$ \\
\hline Hours of ventilation & $217.5 \pm 51.4$ & $104.5 \pm 47.6$ \\
\hline Length hospital stay & $23.0 \pm 1.6$ & $11.3 \pm 1.2$ \\
\hline
\end{tabular}

NIV, non-invasive ventilation; $\mathrm{P} / \mathrm{F}, \mathrm{PaO}_{2} / \mathrm{FIO}_{2}$ ratio; SAPS II, simplified acute physiology score.

Table 2. Patients' characteristics, ventilation approaches and the ventilator settings used in patients treated with non-invasive ventilation who had a positive outcome.

\begin{tabular}{|c|c|c|c|c|c|c|c|c|c|}
\hline Age & Gender & $\begin{array}{l}\text { Pulmonary } \\
\text { lobes }\end{array}$ & $\begin{array}{c}\mathrm{PaO}_{2} / \mathrm{FIO}_{2} \\
\text { (on admission) }\end{array}$ & $\begin{array}{l}\mathrm{PaO}_{2} / \mathrm{FIO}_{2} \\
\text { (after } 1 \mathrm{~h})\end{array}$ & SAPS II & $\begin{array}{l}\text { Ventilator } \\
\text { method }\end{array}$ & $\begin{array}{c}\text { Ventilator } \\
\text { parameters } \\
\left(\mathbf{c m ~} \mathbf{H}_{2} \mathbf{0}\right)\end{array}$ & $\begin{array}{c}\text { Duration } \\
\text { NIV } \\
\text { (h) }\end{array}$ & $\begin{array}{c}\text { Hospital stay } \\
\text { (days) }\end{array}$ \\
\hline 35 & M & 3 & 185 & 310 & 18 & BIPAP (I/E) & $15 / 5$ (I/E) & 96 & 16 \\
\hline 26 & $\mathrm{~F}$ & 3 & 170 & 250 & 22 & PSV & $14 / 6$ & 112 & 15 \\
\hline 31 & M & 3 & 200 & 290 & 16 & CPAP & 15 & 64 & 12 \\
\hline 35 & $\mathrm{M}$ & 4 & 170 & 220 & 20 & PSV & $15 / 5$ & 118 & 15 \\
\hline 63 & M & 4 & 150 & 200 & 26 & BIPAP & $20 / 6$ & 172 & 19 \\
\hline 38 & M & 3 & 185 & 235 & 16 & BIPAP & $14 / 6$ & 86 & 7 \\
\hline 62 & $\mathrm{~F}$ & 3 & 170 & 190 & 18 & BIPAP & $21 / 7$ & 211 & 12 \\
\hline 53 & $\mathrm{~F}$ & 4 & 150 & 170 & 18 & BIPAP & $20 / 7$ & 151 & 11 \\
\hline 30 & M & 3 & 200 & 240 & 18 & CPAP & 12 & 48 & 7 \\
\hline 17 & M & 3 & 185 & 240 & 14 & BIPAP & $20 / 6$ & 66 & 9 \\
\hline 27 & $\mathrm{M}$ & 3 & 150 & 190 & 16 & BIPAP & $15 / 5$ & 70 & 10 \\
\hline 68 & F & 2 & 220 & 290 & 14 & PSV & $12 / 7$ & 66 & 7 \\
\hline
\end{tabular}

SAPS II, simplified acute physiology score; NIV, non-invasive ventilation; BIPAP, bilevel positive airway pressure; I, inspiratory positive airway pressure; E, expiratory positive airway pressure or PEEP positive end-expiratory pressure; PSV, pressure support ventilation; CPAP, continuous positive airway pressure.

Table 3. Statistically significant factors, according to logistical regression analyses and univariate regression analyses associated with successful non-invasive ventilation.

\begin{tabular}{lccc}
\hline & Intubation & NIV & P \\
\hline Gender (M/F) & $3 / 2$ & $9 / 5$ & 0.42 \\
\hline Age & $57.3 \pm 18.6$ & $48.1 \pm 20.6$ & 0.34 \\
\hline Pulmonary lobes & $3.9 \pm 0.6$ & $3.0 \pm 0.6$ & $<0.01$ \\
\hline P/F on admission & $155.0 \pm 21.5$ & $181.2 \pm 26.7$ & 0.21 \\
\hline P/F after 1 h & $166.4 \pm 42.2$ & $239.1 \pm 38.7$ & $<0.001$ \\
\hline SAPS II on admission & $38.7 \pm 3.0$ & $18.3 \pm 2.9$ & $<0.002$ \\
\hline Hours of ventilation & $217.5 \pm 51.4$ & $104.5 \pm 47.6$ & $<0.007$ \\
\hline Length hospital stay & $23.0 \pm 1.6$ & $11.3 \pm 1.2$ & $<0.009$ \\
\hline
\end{tabular}

NIV, non-invasive ventilation; $\mathrm{P} / \mathrm{F}, \mathrm{PaO}_{2} / \mathrm{FIO}_{2}$ ratio. 
A smaller number of pulmonary lobes involved, lower SAPS II values on admission, $\mathrm{P} / \mathrm{F}$ after $1 \mathrm{~h}$ of NIV $\geq 175$ were the independent variables associated with a good outcome after NIV $(\mathrm{P}<0.001)$.

A study flow diagram is provided in Figure 2.

\section{Discussion}

Non-invasive ventilation is often used in cases of acute respiratory failure in order to avoid intubation. Nevertheless, its use in cases of severe hypoxemic respiratory failure is still relatively new and some controversy still remains, with only a few studies available. ${ }^{1,20}$ Recently various studies have been published reporting success rates of $5-100 \%{ }^{8-10,12,21-45} \mathrm{At}$ the beginning of the pandemic, the use of NIV was not recommended for lack of data supporting its safe use in treating patients with acute severe respiratory failure $^{46}$ and because of the high failure rate and the risk of possible consequence given that inappropriate and prolonged use of NIV had been suggested as a possible cause of death probably due to delayed intubation of these patients. ${ }^{47}$ The situation is starting to change and the use of NIV during pandemics and a greater use in general in cases of acute pneumonia-associated respiratory failure is on the increase. But failure rates are still high. Various studies have already been carried out, most of which did not report the degree of respiratory failure (in particular, in cases in which there was NIV failure) understood as $\mathrm{P} / \mathrm{F}$ ratio, the type of ventilator used, ventilation method and parameter settings, and, finally, the number of organs involved in the disease.

Different factors could play a role in NIV failure: number of organs involved, ${ }^{48}$ the seriousness of the disease, ${ }^{1}$ and the response to ventilation. ${ }^{1,49}$ In a recent study of children with ALI/ARDS, Piastra et al..$^{48}$ showed that the extent of organ failure on admission is a strong predictor of NIV failure and that patients with failure of only one organ have a $85.7 \%$ probability of success. The fact that information like this has not been available could be the reason behind the strong criticism concerning the poor efficacy of NIV in severe respiratory failure from H1N1 viral pneumonia. Furthermore, again in a recent study, Pelosi discussed a possible role for chest CT scan to identify patients with a lower possibility of selection for controlled mechanical ventilation. This Author declared that a $\mathrm{PaO}_{2} / \mathrm{FiO}_{2}$ ratio of less than 150 with $\mathrm{FiO}_{2} 100 \%$ and positive end-expiratory pressure (PEEP) $5-10 \mathrm{~cm}$ $\mathrm{H}_{2} \mathrm{O}$, associated with widespread opacity on CT scan, predicted greater suitability for controlled mechanical ventilation. In contrast, a patient with $\mathrm{P} / \mathrm{F}$ over 150 and localized lobular opacity could have a low possibility of being assigned to controlled mechanical ventilation. This type of patient could be treated with

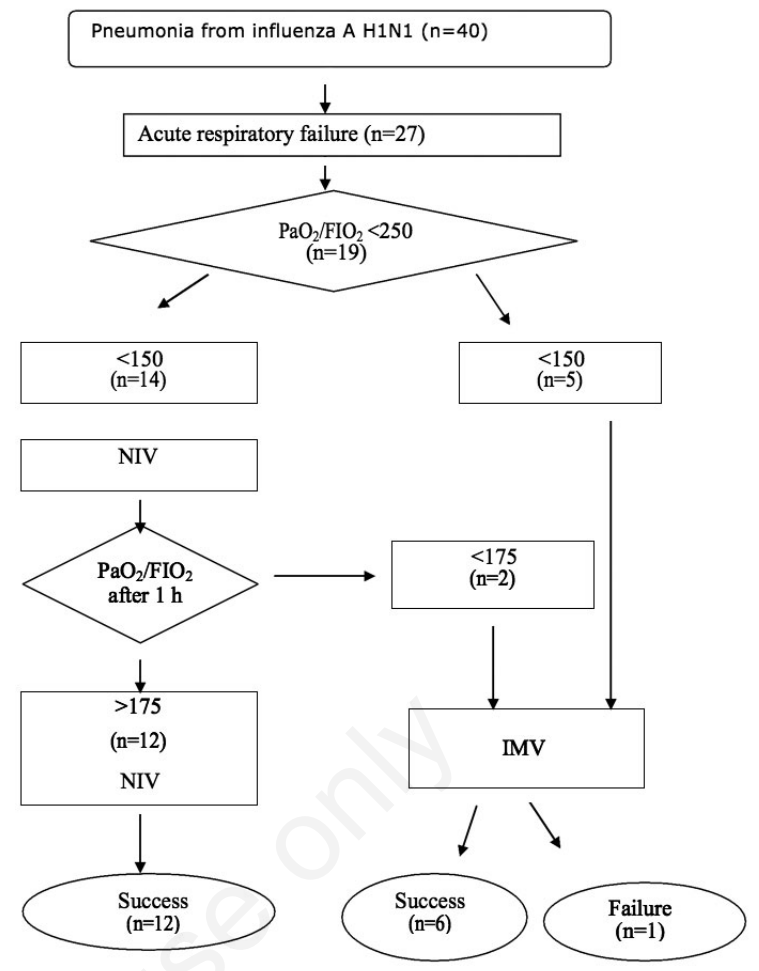

Figure 2. Study flow diagram.

assisted ventilation with flow volumes of $6-8 \mathrm{~mL} / \mathrm{kg}$ and PEEP 5-10 $\mathrm{cm} \mathrm{H}_{2} \mathrm{O} .{ }^{19}$ We used simplified criteria like this on admission to the Emergency Department to select our patients.

Admission to the sub-intensive care unit: lobular opacity, $\mathrm{P} / \mathrm{F}$ ratio over 150 with $\mathrm{FiO}_{2} 60 \%$, SAPS II 34 or below, no multi-organ failure.

Admission to ICU: widespread opacity, $\mathrm{P} / \mathrm{F}$ ratio below 150, SAPS II over 34.

In our study, $73.68 \%$ of patients with severe respiratory failure were treated with NIV of whom $85.7 \%$ with a positive outcome, demonstrating one of the highest success rates for NIV ever reported. ${ }^{31}$ We believe that the reason for this was a rigorous selection procedure to choose patients to be treated, with no really severe cases of respiratory failure or distress $(\mathrm{P} / \mathrm{F} \leq 150)$, the use of chest CT scan to evaluate pulmonary involvement, less serious disease status (SAPS $\leq 34)$, failure of only one organ, rigorous monitoring or factors predicting NIV success such as $\mathrm{P} / \mathrm{F}$ after $1 \mathrm{~h} \geq 175^{1}$ and any changes in indicators of disease in the hours and even days after admission.

Many Authors have expressed their concerns about the use of NIV during a pandemic because of the risk of infection through inhalation via the mask or via the ventilator tube, as these could infect doctors and nursing staff. No cases of contamination have been confirmed in our hospitals that have compromised the health of 
our healthcare operators, even though most patients were treated with NIV. All patients with confirmed influenza A H1N1 infection were kept in isolation and in negative pressure rooms, and preventive measures against infection were adopted (masks, overalls, gloves and alcohol disinfectant gel for the hands). As far as the ventilators are concerned, unaired oro-nasal masks were preferred to limit the spread of infection.

This study has some limitations. Only 2 hospital centers are involved and there is only a small number of cases. It cannot, therefore, be considered to be representative of the situation in Liguria or northern Italy. Also our hospitals are not reference centers for children or pregnant women with H1N1 influenza infection so these patient populations are not included. Finally, mortality rates are extremely low and this makes it impossible to make a comparative analysis of mortality as outcome.

In conclusion, our success rates with NIV show that patients with severe pneumonia from $\mathrm{H} 1 \mathrm{~N} 1$ can benefit from this treatment, thus avoiding the need for invasive ventilation, reducing the incidence of complications, the length of hospital stay and hospital costs. All this can only be achieved if there is a careful selection of suitable patients. As reported above, this approach should be used with great caution and NIV should only be used with non-severe ALI/ARDS profiles (P/F 150) and all patients should be carefully monitored. ${ }^{49,50}$

Physicians should be aware of the pulmonary complications of H1N1 influenza and carefully select patients suitable for NIV. They should also understand that an inappropriate use of NIV for too long $(>24 \mathrm{~h}$ in cases of worsening clinical and hemogasanalytical profiles) ${ }^{51}$ could lead to death due to excessive delay in intubation. ${ }^{46}$

A recent study by Masclans et al. did, however, show that failure of NIV in patients with severe respiratory failure caused by pneumonia from influenza $\mathrm{A}$ H1N1 virus has been associated with mortality rates similar to those reported for patients who underwent immediate intubation. ${ }^{45}$ This finding, if confirmed further would change the idea that use of NIV could cause a delay in invasive treatment and worsen patient prognosis, as stated in the first studies on H1N1 influenza. Physicians expert in the use of NIV can avoid intubation, reduce the incidence of septic shock and improve survival with respect to only high-flow oxygenotherapy in acute respiratory failure caused by pneumonia..$^{52}$ Given the evidence examined, the suggestion could be made to consider ventilation support as early as possible in the initial phase of acute pneumonia-related respiratory failure. Such an approach could have an effective and safe role in reducing the huge demand on beds in the ICU seen particularly during pandemics.

\section{References}

1. Antonelli M, Conti G, Esquinas A, et al. A multiple-Center survey on the use in clinical practice of non-invasive ventilation as a first-Line intervention for acute respiratory distress syndrome. Crit Care Med 2007;35:18-25.

2. Fernandez-Vivas M, Gonzales-Diaz G, Caturla-Such J, et al. Use of non-invasive ventilation in acute respiratory failure. Multicenter study in intensive care. Med Int 2009;33:153-60.

3. Namedys-Silva SA, Hernandez-Garay M, Rivero-Sigarroa E. Non-invasive ventilation for critically ill patients with pandemic H1 2009 influenza A virus infection. Crit Care 2010;14:407.

4. Conti G, Larrsson A, Nava S, Navalesi P. On the role of non-invasive ventilation (NIV) to treat patients during the H1N1 influenza pandemic. Last updated: November 2009. Available from: http://dev.ersnet.org/uploads/Document/63/WEB_CHEMIN_5410_1258624143.pdf

5. Ramsey CD, Funk D, Miller RR, Kurnar A.Ventilator management for hypoxemic Respiratory failure attributable to H1N1 novel swine origin influenza virus. Crit Care Med 2010;38:58-65.

6. Hui D, Lee N, Chan PK. Clinical management of pandemic 2009 influenza A (H1N1) infection. Chest 2010;137:916-25.

7. Kaufman MA, Duke GJ, McGain F, et al. Life-threatening respiratory failure from H1N1 influenza 09 (human swine Influenza). MJA 2009;191:154-6.

8. Rello J, Rodriguez A, Ibanez P, et al. Intensive care Adult patients with severe respiratory failure caused by Influenza A (H1N1) in Spain. Crit Care 2009;13:R148.

9. Farias JA, Fernandez A, Monteverde E, et al. Critically ill Infants and children with influenza A (H1N1) in pediatric intensive care units in Argentina. Intensive Care Med 2010;36:1015-22.

10. Dijbré M, Berkane N, Salengro A, et al. Non-invasive management of acute respiratory distress syndrome related to Influenza A (H1N1) virus pneumonia in a pregnant women. Intensive Care Med 2010;36:373-4.

11. Winck JC, Marinho A. Non-invasive ventilation in acute respiratory failure related to 2009 pandemic influenza A/H1N1 virus infection. Crit Care 2010;14:408.

12. Estennsoro E, Rios FG, Apezteguia C. Pandemic 2009 Influenza A in Argentina: a study of 337 patients on mechanical ventilation. Am J Resp Crit Care Med 2010; 182:41-8.

13. Rodriguez A, Lisboa T, Rello J. Pandemic influenza A (H1N1) in the intensive care unit: what have we learned? Arch Broncopneumol 2010;46:24-31.

14. Ramsey C, Kumar A. H1N1: viral pneumonia as a cause of acute respiratory distress syndrome. Curr Opin Crit Care 2011;17:64-71.

15. Cabrini L, Silvani P, Landoni G, et al. Non-invasive ventilation in H1N1-correlated severe ARDS in a pregnant woman: please be cautious! Int Care Med 2010;26:1782.

16. Winck JC, Goncalves M. H1N1 infection and acute respiratory failure: can we give non-invasive ventilation a chance? Rev Port Pneumol 2010;16:907-11.

17. Nicolini A, Claudio S, Rao F, et al. Influenza A (H1N1) associated pneumonia. J Bras Pneumol 2011;37:621-7.

18. Ugcun I, Yildrm H, Metinas M, Ak G. The efficacy of 
non-invasive positive pressure ventilation in ARDS: a controlled cohort study. Tuberk Toraks Derg 2010; 58:16-24

19. Pelosi P, Rocco PRM, Gama de Abreu MG. Use of computed tomography scanning to guide lung recruitment and adjust positive-end expiratory pressure. Curr Opin Crit Care 2011;17:268-74.

20. Rana S, Jenad H, Gay PC, et al. Failure of non-invasive ventilation in patients with acute lung injury: observational cohort study. Crit Care 2006;10:R79.

21. Kumar A, Zarychanski R, Pinto R, et al. Critically ill patients with 2009 influenza A (H1N1) infection in Canada. JAMA 2009;302:1872-9.

22. Ugarte S, Arancibia F, Soto R. Influenza A pandemics: Clinical and organizational aspects: the experience in Chile. Crit Care Med 2010;38:e133-7.

23. Dominguez-Cherit G, Lapinsky SE, Macias AE, et al. Critically ill patients with 2009 influenza A (H1N1) in Mexico. JAMA 2009;302:1880-7.

24. Miller RR 3rd, Markevitz BA, Rolfs RT, et al. Clinical findings and demographic factors associated with intensive care unit admission in Utah due to 2009 novel influenza A (H1N1) infection. Chest 2010;137:752-8.

25. Chacko J, Gagan B, Ashok E, et al. Critically ill patients with 2009 H1N1 infection in an Indian ICU. Lung India 2010;14:77-82.

26. Belenguer-Muncharaz A, Reig-Valero R, Altaba-Tena S, et al. Utlizacion de la ventilacion mecanica no invasive en neumonia grave por virus H1N1. Med Intensiva 2011;35:470-7.

27. Grasselli G, Bombino M, Patroniti N, et al. Management of acute respiratory complications from influenza A (H1N1) infection: experience of a tertiary-level. Intensive Care Unit Min Anest 2011;77:1-8.

28. Kirakli C, Tatar D, Cimen P, et al. Survival from severe pandemic H1N1 in urban and rural Turkey: a case series. Resp Care 2011:56:790-5.

29. Riquelme R, Torres A, Rioseco ML, et al. Influenza pneumonia: a comparison between seasonal influenza virus and H1N1 pandemic. Eur Resp J 2011;38:106-11.

30. Cornejo R, Tobar E, Diaz G, et al. Systematic approach for severe respiratory failure due to novel A (H1N1) influenza. Minerva Anestesiol 2011;77:510-21.

31. Timenetsky KT, Aquino SHC, Saghabi C, et al. High success and low mortality rates with non-invasive ventilation in influenza A H1N1 patients in a tertiary hospital. BMC Res Note 2011;4:375.

32. Bai L, Gu L, Cao B, et al. Clinical features of pneumonia caused by Influenza A (H1N1) virus in Bejing, China. Chest 2011;139:1156-64.

33. Adiguzel N, Karakurt Z, Kalamanoglu M, et al. Influenza A (H1N1) virus pneumonia in intensive care unit. Tuberk Tor Derg 2010;58:278-85.

34. Nin N, Soto L, Hurtado J, et al. Clinical characteristics and outcomes of patients with 2009 influenza A (H1N1) virus infection with respiratory failure requiring mechanical ventilation. J Crit Care 2011;26:186-92
35. Camous L, Lemiale V, Canet E, et al. Clinical features of H1N1 2009 infection in critically ill immunocompromised patients. Care 2011;14:139-40.

36. Teke T, Coskun R, Sungur M, et al. 2009 H1n1 Influenza and experience in three critical care units. Int $\mathrm{J}$ Med Sci 2011;8:270-7.

37. Xi X, Xu Y, Jiang L, et al. Hospitalized adult patients with 2009 influenza A (H1N1) in Beijing, China. Risk factors for hospital mortality. BMC Infect Dis 2010;10:256-69.

38. Li H, Ma RC. Clinical analysis of 75 patients with severe influenza A H1N1 in Qinghai Province. Zhon W Zhon Bing J J Yi Xue 2010;22:164-5.

39. Paredes G, Cevallos C. Acute respiratory distress syndrome during the $2009 \mathrm{H} 1 \mathrm{~N} 1$ influenza A pandemic in Ecuador. Med Intensiva 2010;34:310-7.

40. Ellington SR, Hartmann LK, Acosta M, et al. Pandemic 2009 influenza A (H1N1) in 71 critically ill pregnant women in California. Am J Obs Gynecol 2011;S21-30.

41. Elbahlawan L, Gaur AH, Furman W, et al. Severe H1N1-associated acute respiratory failure in immunocompromised children. Pediatr Blood Cancer 2011;57:625-8.

42. Liu L, Zhang R-F, Lu H-Z, et al. Sixty-two severe and critical patients with 2009 influenza A (H1N1) in Shanghai, China. Chin Med J 2011;124:1662-6.

43. Rios FG, Estenssoro E, Villarejo F, et al. Lung function and organ disfunction in 178 patients requiring mechanical ventilation during the 2009 influenza A(H1N1) pandemic. Crit Care 2011;15:R201.

44. Zhang PJ, Li XL, Cao B, et al. Clinical features and risk factors for severe and critical pregnant women with 2009 pandemic H1N1 influenza Infection in China. BMC Infect Dis 2012;12:29-37.

45. Masclans JR, Perez M, Almirall J, et al. Early non-invasive ventilation treatment for severe influenza pneumonia. Clin Microb Infect 2012. [In press].

46. Benditt JO, Kacmarek RM, Mehta S. Novel uses of noninvasive ventilation. Respir Care 2009;54:212-9.

47. Gay PC. Complication of non-invasive ventilation in acute care. Respir Care 2009;54:246-57.

48. Piastra M, De Luca D, Stival E, et al. The number of failing Organs predicts non-invasive ventilation failure in children with ALI/ARDS. Int Care Med 2011; 37:1510-6.

49. Ucgun I, Vildirim H, Metintas M, Ak G. The efficacy of non-invasive ventilation in ARDS: a controlled cohort study. Tuberk Tor Derg 2010;58:16-24.

50. Conti G, Costa R. Non invasive ventilation in patients with hypoxemic non hypercapnic Acute respiratory failure. Clin Pulm Med 2011;18:83-7.

51. Sigh A, Sigh J. Non-invasive ventilation in acute respiratory failure due to H1N1 influenza: a word of caution. Lung India 2011;28:151.

52. Ferrer M, Esquinas A, Leon M, et al. Noninvasive Ventilation in acute respiratory failure. Am J Resp Crit Care Med 2003;168:1438-44. 